\title{
Toleransi Antar Umat Beragama melalui Penerapan Pembelajaran Pendidikan Agama Islam (Studi Kasus : SMAS Paramarta 1 Seputih Banyak)
}

\section{Interreligious Tolerance through Application of Islamic Religious Education Learning (Case Study: SMAS Paramarta 1 Seputih Banyak)}

\author{
Choirul Anwar ${ }^{1}$, Syamsuri Ali ${ }^{1}$, Ardo Hutama Putra ${ }^{1^{*}}$ \\ ${ }^{1}$ Universitas Islam Negeri Raden Intan Lampung. Jalan Endro Suratmin, Sukarame, Bandar Lampung \\ 35133, Indonesia. \\ *Corresponding Author. E-mail: ardhop1@gmail.com
}

\begin{abstract}
Abstrak
Negara Indonesia merupakan negera yang terdiri dari beragam suku, agama, budaya dan kepercayaan. Maka perlu yang Namanya pembinaan toleransi, tekhusus toleransi antar umat beragama. Tujuan penelitian ini adalah untuk mengetahui bagaimana penerapan pembelajaran agama islam dalam membina toleransi antar umat beragama di SMAS Paramarta 1 Seputih Banyak. Metode pendekatan penelitian kualitaitify yang berisikan pendeskripsian mengenai data yang diperoleh dari lapangan, pengumpulan datanya dilakukan dengan menggunakan observasi, wawancara dan dokumentasi. Hasil dari penelitian ini adalah bagaimana peran pembelajaran agama islam dalam membina toleransi antar umat beragama di SMAS Paramarta 1 seputih Banyak yaitu (1) dengan mengaitkan nilai-nilai toleransi dalam perencanaan pembelajaran, selanjutnya (2) pendidik selalu memasukkan nilai toleransi antar umat beragama di dalam materi, selain itu (3) Adanya pembinaan dan pengamatan toleransi antar umat beragama, (4) Pembelajaran agama islam boleh diikuti oleh siswa yang non agama islam, (5) Percontohan yang dilakukan pendidik dalam hidup bertoleransi, dan (6) Adanya kegiatan hari-hari besar keagamaan dan gotong royong.

Kata kunci: Pembelajaran, Pembinaan Toleransi Antarumat Beragama, Pendidikan Agama Islam

Abstract

Indonesia is a country consisting of various ethnic groups, religions, cultures and beliefs. So it is necessary to develop tolerance, especially tolerance between religious communities. The purpose of this study was to find out how the application of Islamic religious learning in fostering inter-religious tolerance at SMAS Paramarta 1 Seputih Banyak. The qualitative research approach method contains a description of the data obtained from the field, the data collection is carried out using observation, interviews and documentation. The results of this study are how the role of Islamic religious learning in fostering inter-religious tolerance at SMAS Paramarta 1 Seputih Banyak, namely (1) by linking tolerance values in learning planning, then (2) educators always include the value of inter-religious tolerance in the learning process. material, in addition (3) There is guidance and observation of tolerance between religious communities, (4) Islamic religious learning may be followed by non-Muslim students, (5) Pilots by educators in tolerant life, and (6) There are daily activities religious holidays and mutual cooperation.
\end{abstract}

Keywords: Learning, Fostering Inter-religious Tolerance, Islamic Religious Education

\section{PENDAHULUAN}

$\begin{array}{ccc}\text { pendidikan } & \text { Agama } & \text { Islam } \\ \text { mempunyai peran } & \text { yang urgen } & \text { dalam }\end{array}$ membentuk kepribadian seseorang sebagai alat dalam mengarungi kehidupan yang semakin maju (Samsudin, 2019). Pendidikan merupakan usaha dasar dan 
terencana untuk mewujudkan suasana belajar dan proses pembelajaran agar peserta didik aktif dalam mengembangkan potensi dirinya untuk memiliki spiritual keagamaan, pengendalian diri, kepribadian, kecerdasan akhlak mulia, serta keterampilan (Asy'ari, 2014; Wibawa et al., 2018) yang di perlukan dirinya dan masyarakat. Di samping itu, pendidikan agama juga merupakan benteng pertahanan menghadapi dekadensi moral (Priyanto, 2020) bagi generasi muda muslim. Oleh karna itu pendidikan agama harus dimasukan ke dalam program pendidikan yang diikuti oleh seluruh pelajar islam. Maka pendidikan agama islam perlu dibangkitkan cinta kasih dan saling percaya antara anak-anak yang berlainan agama.

Tujuan dari pendidikan agama islam yaitu meningkatkan keimanan, pemahaman, penghayatan, dan pengamalan terhadap agama Islam, sehingga menjadi manusia muslim yang beriman dan bertakwa kepada Allah SWT (Arsyad et al., 2020). Bentuk pencapaian dari tujuan pendidikan agama islam memiliki peran dalam mampu meningkatkan dan mengembangkan kualitas hidupnya sendiri (Raharjo, 2010).

Pendidikan agama islam merupakan pembelajaran yang diharapkan membina, mengarahkan serta memberikan motivasi terkait toleransi antar umat beragama kepada peserta didik (Djollong \& Akbar, 2019). Dengan memberikan pendidikan tentang toleransi antar umat beragama, harapannya peserta didik bisa menerapkan dalam kehidupan sehari-hari sehinga peserta didik memiliki sifat dan sikap yang toleran, adil, demokratis dan humanis dalam perbedaan (Malla, 2017).

Indonesia merupakan negara multikultural yang keanekaragamannya diakui oleh bangsa-bangsa lain (Alzana \& Harmawati, 2021), bermacam budaya, suku dan keyakinan sudah berbeda-beda. Sehingga perlu pemahaman tentang budaya toleransi terhadap warga negara di Indonesia, khususnya di kalangan pelajar yang sedang giat-giatnya menggali ilmu. Maka perlu yang namanya pendidikan tentang nilai-nilai toleransi antar umat beragama dalam penerapannya sehari-hari. Dengan diterapkannya Pembelajaran Pendidikan Agama Islam diharapkan siswa bisa saling menghargai dan menghormati perbedaan keyakinan yang ada di sekitarnya (Umar, 2018).

Toleransi sudah menjadi hal yang biasa bahkan menjadi sunatullah yang menjadi corak bagi manusia yang hidup di alam semesta ini. Toleran terhadap warna kulit, bentuk tubuh, bahkan sampai ke bidang peribadatan. toleransi dalam ajaran islam adalah Islam memperbolehkan umatnya berhubungan dengan umat agama lain. Toleransi antarumat beragama dalam batasan muamalah. Adapun dalam aqidah dan ibadah secara tegas melarang umtuk bertoleransi (Damanik, 2019).

Toleransi terdapat macamnya, salah satunya adalah toleransi antar umat beragama yang merupakan salah satu bentuk toleransi yang sangat penting di kalangan peserta didik. hal ini di latar belakangi oleh keanaekaragaman agama yang ada di setiap lembaga pendidikan, sehingga dengan diwujudkan pemahaman toleransi antar umat beragama dalam setiap aktifitas pembelajaran maupun diluar pembelajaran harapanya peserta didik lebih paham dan mengetahui bagaimana dia hidup di tengah-tengah perbedaan agama.

Toleransi antar umat beragama sangat diperlukan dalam menjaga keharmonisan dalam kehidupan bermasyarakat yang terdiri dari latar belakang agama yang berbeda (Setyorini \& Yani, 2020). Dengan toleransi bisa dipastikan kehidupan yang rukun, baik, terbuka, damai dan penuh penghargaan akan terjalin di lingkungan pendidikan dan masyarakat. Toleransi antar umat 
beragama bukanlah toleransi dalam masalah-masalah keagamaan, melainkan perwujudan sikap keberagaman pemeluk suatu agama dalam pergaulan hidup antara orang yang tidak seagama.

Merealisasikan

pembelajaran

Pendidikan Agama Islam dalam membina toleransi Antar umat beragama maka perlu menerapkan pembelajaran pendidikan agama islam yang menanamkan nilai-nilai toleransi antar umat beragama (Yunus, 2017) dalam keterlibatannya di dalam pembelajaran baik materi, metode dan cara penanaman sampai ke tahap evaluasi pembelajaran tentang toleransi antara umat beragama yang digunakan oleh pendidik dalam menyampaikan materi pembelajaran. Pembinaan peserta didik difokuskan pada pengembangan seluruh aspek kepribadian secara terpadu untuk membentuk sumberdaya manusia yang bermutu tinggi agar mampu menjawab tantangan kehidupan di masa yang akan datang.

Dalam pembinaan dalam pembelajaran terdapat beberapa masalah didalamnya, misalkan perencanaan pembelajaran yang tidak memasukkan nilai-nilai toleransi antar umat agama dan jarang ada penanaman nilai-nilai toleransi ketika dalam penyampaian materi atau yang lainnya, sehingga tujuan dari pembinaan itu kurang maksimal dalam pencapainya. Pembinaan erat hubungannya dengan peran pendidik dan peran seluruh perangkat pembelajaran yang akan di sampaikan kepeada peserta didik, sehingga pembinaan merupakan faktor terpenting dalam mempertahankan seluruh capaian yang sudah dicapai.

Toleransi sudah ada dalam lingkungan pendidikan SMAS Paramarta 1 Seputih Banyak terkhusus toleransi anatar umat beragama baik itu dilingkup pendidik sampai peserta didik semua capaian itu tak luput dari proses pembelajaran yang sudah diterapkan di sekolah SMA Paramarta 1 kepada peserta didik. Dalam melakukan pembinaan itulah terdapat beberapa masalah yang dialami oleh lembaga pendidikan, sehingga pembinaan merupakan bentuk perawatan agar toleransi ini tetap ada dan berlangsung di lembaga pendidikan.

SMAS Paramarta 1 Seputih Banyak merupakan sekolah swasta yang beralamatkan di Desa Sumber Baru, kecamatan Seputih Banyak, Kabupaten Lampung Tengah. SMAS PARAMARTA 1 merupakan sekolahan swasta yang paling favorit di kecamatan Seputih. Memiliki jumlah siswa sebanyak 278 siswa dengan rincian siswa laki-laki berjumlah 150 siswa dan jumlah siswa perempuan sebanyak 128 siswa. Dengan jumlah siswa beragama katolik sebanyak 5 orang, hindu 98 orang, dan islam 175 orang.

SMAS Paramarta 1 Seputih Banyak merupakan sekolah swasta umum atau dikatakan sekolah yang menerima jenis siswa tanpa harus memilki kesamaan dalam agama. Perbedaan suku, agama dan budaya merupakan ciri khas dari sekolah SMAS Paramarta 1 Seputih Banyak, perbandingan jumlah siswa di sekolah ini hampir setara berdasar jenis kelamin. Namun jika menoleh jumlah siswa berdasarkan agamanya, yang beragama islam di sekolah ini memiliki jumlah yang lebih banyak dibandingkan jumlah siswa yang memeluk agama selain islam. Namun berbedaan yang sedemikian rupa bukan menjadi perbedaan yang signifikan bagi siswa SMA Paramarta 1 dalam melakukan interaksi sosial dalam lingkungan sosial, antar siswa hidup saling berdampingan dan saling melengkapi kekurangan antara mereka ini tercerminkan ketika siswa aktif dilingkungan pembelajaran dan di area sekolah yang bercengkrama sesama teman dan guru yang notabenya berbeda kepercayaan yang dianut. Ini semua menggambarkan sikap toleran yang dimiliki oleh sisiwa dan guru sangat tingga dan menjauhi sikap ekslusif sesame masyarakat sekolah. 
Nilai-nilai Toleransi telah nampak jelas di sekolahan SMAS Paramarta 1 Seputih Banyak dikarenakan telah terdapat pembelajaran pendidikan agama islam yang mengandung nilai-nilai toleransi dari pemahaman guru agama maupun materi yang berisikan dengan nilai-nilai Toleransi hal ini ditegaskan kembali atas penjelasan dari guru pendidikan agama islam yang mengatakan bahwa siwa-siswi di sekolahan SMAS Paramarta 1 ini saling membantu dan hidup berdampingan dalam kegiatan sehari-hari di lingkungan sekolah, dengan dibuktikan bahwasanya siswa-siswa saling membantu ketika melakukan persiapan kegiatan peribadatan agama mereka membantu dalam menyiapkan alat-alat dan perlengakapan beribadahan, misalkan siswa yang beragama muslim membantu menyiapkan acara besar peribadatan umat hindu di Aula SMAS Paramarta dan begitu pula sebaliknya, walaupun mereka tidak ikut merayakan namun ikut membantu dalam persiapan agara berjalanya acara tersebut. Ini merupakan cerminan sikap toleransi yang dimiliki oleh siswa-siswi di SMAS Paramarta 1 Seputih Banyak.

Melihat latar belakang diatas, bahwa sudah terlihat secara gamblang dalam lingkungan pendidikan SMAS Paramarta sudah memiliki nilai-nilai toleransi antar umat beragama sehingga dalam perawatan jangka panjang perlu diterapkannya pembinaan kepada sisiwa tentang nila-nilai toleransi antar umat beragama agar nilai-nilai toleransi ini bisa tetap terpatri dalam jiwa peserta didik. pembinaan itu semua bisa terlaksana karna adanya wadah dalam penyampain tujuan, dan salah satu wadah yang tepat itu disampaikan melalui pembelajaran pendidikan agama islam di SMAS Paramarta 1 Seputih Banyak.

Dalam penyampaian materi pendidikan agama islam yang mengandung nilai-nilai toleransi antar umat beragama, maka tak terlepas dari perencanaan, pembelajaran, pelaksanaan pembelajaran, dan evaluasi pembelajaran. Tujuan pembinaan ini bisa dicapai jika unsur dalam pembelajaran itu dikaitkan dengan nilai-nilai pembinaan toleransi anatar umat beragama. Sehingga perlu strategi dan taktik yang cerdik seorang pendidik sehingga proses pembelajaran ini bisa terlaksana dengan sukses.

Peneliti memilih SMAS PARAMARTA 1 Seputih Banyak sebagai objek penelitian hal ini di latar belakangi dengan fenomena keberagaman yang ada. Karana semua keberagaman yang telah ada ini terbebankan kepada guru pendidikan agama islam yang menjadi garda terdepan dalam terwujudnya sikap toleransi setiap peserta didik. Maka pemilihan materi, metode dan evaluasi yang kurang tepat tentu akan menghambat pembelajaran pendidikan agama islam, sehingga peniliti memfokuskan penelitian di SMAS Paramarta 1.

Sudah banyak penelitian sejenis yang sudah dilakukan, antara lain metode yang digunakan pendidik dalam pengenalan sikap toleran meliputi metode keteladanan, bimbingan, dan pembiasaan. Implementasinya dalam kegiatan pembelajaran klasikal dan online (dalam jaringan) serta dalam kegiatan penunjang pendidikan Islam (Huda et al., 2021). Proses pembelajaran pendidikan agama Islam dengan metode pluralisme dapat membentuk karakter peserta didik, baik yang beragama Hindu maupun Islam yang humanis, toleran dan inklusif (Saihu \& Aziz, 2020). Peran guru PAI sebagai pendidik dan motivator dalam membina etika toleransi antar umat beragam siswa sudah sangat baik (Mula et al., 2019).

Berdasarkan uraian tersebut, pada penelitian ini bertujuan untuk mengetahui bagaimana penerapan pembelajaran agama islam dalam membina toleransi antar umat beragama di SMAS Paramarta 1 Seputih Banyak.

\section{METODE}


Penelitian ini menggunakan jenis penelitian kualitatif dengan pendekatan kualitatif deskriptif. Triangulasi data di lakukan dengan menggunakan teknik berbeda yaitu wawancara, observasi, dan dokumentasi. Triangulasi ini selain digunakan untuk mengecek kebenaran data juga dilakukan memperkaya data. Triangulasi dalam pengujian kredibilitas diartikan sebagai pengecekan data dari sebagai sumber dengan berbagai cara, dan berbagai waktu. Dengan demikian terdapat triangulasi sumber, triangulasi teknik dan triangulasi waktu.

\section{HASIL DAN PEMBAHASAN}

Dalam perencanaan pebelajaran yang dimasukan selalu mengaitkan nilai-nilai toleransi adalah guru pendidikan agama islam yang ada di SMA Paramarta 1 selalu berusaha merancang kegiatan pembelajaran yang didalamnya selalu tertanam tentang materi-materi tentang toleransi, walaupun apapun jenis rancangan pembelajaran guru SMAS Paramarta selalu memasukkan nilai unsure toleransi dalam rancangan pelaksanaan pembelajaran. Hal ini sesuai dengan hakikat pembelajaran menurut ahmad mujit, Pemebelajaran pada hakikatnya merupakan interkasi aktif antara pendidik dan peserta didik.interaksi yang diamana guru dapat memebuat anak didik belajar dengan mudah dan terdorong oleh kemauanya untuk memepelajari semua materi yang telah diatur dan disusun di dalam kurikulum yang telah dipakai.oleh karna itu hendaknya setiap pembelajaran hendaknya berupaya menjabarkan nilai-nilai yanag terkandung didalam kurikulum dan mengkorelasiakan dengan kenyataan yang ada di sekitar peserta didik.

Perencanaan merupakan alat yang digunakan dalam mencapai tujuan dari pembelajran. Perencanaan yang disusun haruslah berpatokan dari kurikulum yanberlaku sehingga materi yang diajarkan sesuai dengan kebutuhan siswa pada saat pembelajaran dilangsungkan.

Menurut Syaiful perencanaan pembelajaran ialah proses pemanfaatan dan penetapan sumber daya menjadi satu sehingga diharapkan dapat membantu menunjang stiap kegiatan yang dilaksanakan agar lebih efektif dan efesien untuk mencapai sebuah tujuan pembelajaran. ${ }^{1}$

Temuan perencanaan pembelajaran peendidikan agama islam yang membinan toleransi antar umat beragama di SMAS Paramarta 1 Seputih Banyak yang ada didalam silabus dan RPP yang sudah ada, adapun RPP yang mengandung pembelajaran yang dapat membina toleransi dan mengandung indikator tentang nilai-nilai toleransi diantaranya : tolong menolong, toleransi, gotong royong, demokrasi, persatuan dan kedamaian.

Semua idikator diatas yang mengandung nilai-nilai toleransi selanjutnya pendidik menyusun rancangan pembelajaran yang mencerminkan nuansa pembinaan toleransi antarumat beragama yang ada di SMAS Paramarta 1 Seputih Banyak. Dan diarapkan ketika siswa sudah menerima perlakuan dari pendidik siswa dapat menerima maksud meteri yang disampaikan dan dapat membina tolerasi anatar umat beragama siswa disekolah.

\section{KESIMPULAN DAN SARAN}

\footnotetext{
${ }^{1}$ Saiful Sagala, konsep dan makna

pembelajran, (Bandung: Alfabeta, 2003), h,141
} 
Berdasarkan hasil penelitian, dapat disimpulkan sebagai berikut: 1) Banyak yaitu (1) dengan mengaitkan nilai-nilai toleransi dalam perencanaan pembelajaran, selanjutnya (2) pendidik selalu memasukkan nilai toleransi antar umat beragama di dalam materi, selain itu (3) Adanya pembinaan dan pengamatan toleransi antar umat beragama, (4) Pembelajaran agama islam boleh diikuti oleh siswa yang non agama islam, (5) Percontohan yang dilakukan pendidik dalam hidup bertoleransi, dan (6) Adanya kegiatan hari-hari besar keagamaan dan gotong royong.

\section{REFERENSI}

Alzana, A. W., \& Harmawati, Y. (2021). Pendidikan Pancasila sebagai pendidikan multikultural. Jurnal Pendidikan Kewarganegaraan Undiksha, 9(1), 52-57. http://ejournal.unipma.ac.id/index.php/citi zenship/article/view/2370

Arsyad, A., Sulfemi, W. B., \& Fajartriani, T. (2020). Penguatan Motivasi Shalat Dan Karakter Peserta Didik Melalui Pendekatan Pembelajaran Kontekstual Pada Mata Pelajaran Pendidikan Agama Islam. POTENSIA: Jurnal Kependidikan Islam, 6(2), 185-204. https://doi.org/10.24014/potensia. v6i2.9662

Asy'ari, M. K. (2014). Metode Pendidikan Islam. Qathruna, 1(1), 193-205.

Damanik, N. (2019). Toleransi Dalam Islam. Shahih: Jurnal Ilmu Kewahyuan, 2(1), 1-27.

Djollong, A. F., \& Akbar, A. (2019). Peran Guru Pendidikan Agama Islam Dalam Penanaman Nilai-Nilai Toleransi Antar Ummat Beragama Peserta Didik Untuk Mewujudkan Kerukunan. Al-'Ibrah: Jurnal Pemikiran Dan Pendidikan Islam, 8(1), 72-92. https://www.umpar.ac.id/jurnal/in dex.php/ibrah/article/view/22

Huda, M. M., Falah, R. Z., Amanina, N., \& Mubarok, M. A. (2021). Internalisasi Sikap Toleransi Melalui Pembelajaran PAI di Sekolah Indonesia Den Haag. Edification Journal, 3(2), 191-210. https://doi.org/10.37092/ej.v3i2.2 58

Malla, H. A. B. (2017). Pembelajaran Pendidikan Agama Islam Berbasis Multikultural Humanistik dalam Membentuk Budaya Toleransi Peserta Didik Di SMA Negeri Model Madani Palu, Sulawesi Tengah. Inferensi, 11(1), 163. https://doi.org/10.18326/infsl3.v1 1i1.163-186

Mula, D. A., Damopolii, M., \& Buhungo, R. A. (2019). Peran Guru PAI Dalam Membina Etika Toleransi Siswa Antar Umat Beragama Siswa di SMK Negeri 1 Limboto. PEKERTI: Jurnal Pendidikan Agama Islam \& Budi Pekerti Volume, 1(2), 42-57.

Priyanto, A. (2020). Pendidikan Islam dalam Era Revolusi Industri 4.0. JPAI: Jurnal Pendidikan Agama Islam, 6(2), 80-89. https://doi.org/10.18860/jpai.v6i2. 9072

Raharjo, S. B. (2010). Pendidikan Karakter Sebagai Upaya Menciptakan Akhlak Mulia. Jurnal Pendidikan Dan Kebudayaan, 16(3), 229-238. https://doi.org/10.30651/else.v3i2. 3011

Saihu, M. M., \& Aziz, A. (2020). Implementasi Metode Pendidikan Pluralisme Dalam Mata Pelajaran Pendidikan Agama Islam. Belajea; Jurnal Pendidikan Islam, 5(1), 131150.

https://doi.org/10.29240/belajea.v $5 i 1.1037$

Samsudin, S. (2019). Peran Pendidikan Agama Islam dalam Membentuk Kepribadian di Era Disrupsi. Jurnal Pemikiran Keislaman, 30(1), 148- 
Ensiklopedia, 01 (01), 2021 - 35

Choirul Anwar, Syamsuri Ali, Ardo Hutama Putra

165.

https://doi.org/10.33367/tribakti.v $30 \mathrm{i} 1.666$

Setyorini, W., \& Yani, M. T. (2020). Interaksi Sosial Masyarakat Dalam Menjaga Toleransi Antar Umat Beragama (Desa Gumeng Kecamatan Jenawi Kabupaten Karanganyar). Kajian Moral Dan Kewarganegaraan, 8(3), 1078-1093.

Umar, M. (2018). Pembinaan Kedamaian Hidup Beragama melalui Optimalisasi Pendidikan Agama. Jurnal Ilmiah Iqra', 10(1), 1-38. https://doi.org/10.30984/jii.v10i1. 588

Wibawa, A. P., Qonita, A., Dwiyanto, F. A., \& Haviluddin. (2018). Perbandingan Metode Prediksi pada Bidang Bisnis dan Keuangan. Prosiding Seminar Ilmu Komputer Dan Teknologi Informasi, 3(1), 129-133.

Yunus, M. (2017). IMPLEMENTASI NILAINILAI TOLERANSI BERAGAMA PADA PEMBELAJARAN PENDIDIKAN AGAMA ISLAM. $A L-$ ISHLAH: Jurnal Pendidikan Islam, 15(2), 166-187. https://doi.org/10.35905/alishlah.v $15 \mathrm{i} 2.566$ 